\title{
Child Psychodynamic Psychotherapy and Therapist Pregnancy: Systematic Case Study ${ }^{1}$
}

\author{
Fernanda Munhoz Driemeier Schmidt², Marina Bento Gastaud², Vera Regina Röhnelt Ramires ${ }^{2}$ \\ ${ }^{2}$ Universidade do Vale do Rio dos Sinos, São Leopoldo-RS, Brazil
}

\begin{abstract}
The present study aimed to describe the characteristics of the psychodynamic psychotherapeutic process of a child with a pregnant therapist and to identify possible repercussions of this pregnancy in the treatment. Adescriptive, longitudinal study was conducted, based on systematic single case study procedure. The participants were an eight-year-old girl and her therapist who became pregnant during treatment. Forty psychotherapeutic sessions were analyzed through Child Psychotherapy Q-Set procedure. The therapeutic process was divided into four periods related to the therapist's pregnancy: (1) the therapist was not pregnant; (2) therapist knew of her pregnancy but the topic had not been verbalized; (3) the pregnancy was treated in the therapeutic setting; (4) return of maternity leave. The results demonstrated that the therapist has adopted a less neutral stance, used less limits, and breaks and pauses in treatment were increasingly discussed. It was concluded that the therapist's pregnancy influences the therapeutic setting in a marked way.
\end{abstract}

Keywords: psychoanalytic psychotherapy, child psychotherapy, psychotherapeutic process

\section{Psicoterapia Psicodinâmica de Crianças e Gravidez da Terapeuta: Estudo de Caso Sistemático}

\begin{abstract}
Resumo: O presente estudo buscou descrever as características do processo psicoterápico psicodinâmico de uma criança com uma terapeuta grávida e identificar possíveis repercussões dessa gravidez no tratamento. Realizou-se um estudo descritivo, longitudinal, baseado no procedimento de estudo de caso único sistemático. Participaram uma menina de oito anos de idade e sua terapeuta que engravidou durante o tratamento. Foram analisadas 40 sessões da psicoterapia por meio do Child Psychotherapy Q-Set. O processo terapêutico foi dividido em quatro períodos de acordo com a gravidez da terapeuta: (1) terapeuta não estava grávida; (2) terapeuta sabia de sua gestação, mas o assunto não havia sido verbalizado; (3) assunto foi tratado no setting terapêutico; (4) retorno da licença maternidade. Os resultados demonstraram uma diminuição da neutralidade e da colocação de limites, discussão de pausas e interrupções no tratamento. Concluiu-se que a gravidez da terapeuta influencia o setting terapêutico de forma acentuada.
\end{abstract}

Palavras-chave: psicoterapia psicanalítica, psicoterapia da criança, processo psicoterapêutico

\section{Psicoterapia Psicodinámica de Niños y Embarazo de Terapeuta: Estudio de Caso Sistemático}

\begin{abstract}
Resumen: El presente estudio buscó describir las características del proceso psicoterápico psicodinámico de una niña con una terapeuta embarazada e identificar posibles repercusiones de ese embarazo en el tratamiento. Se realizó un estudio descriptivo, longitudinal, basado en el procedimiento de estudio de caso único sistemático. Participaron una niña de ocho años de edad y su terapeuta que se quedó embarazada durante el tratamiento. Se analizaron 40 sesiones de la psicoterapia a través del Child Psychotherapy Q-Set. El proceso terapéutico se dividió en cuatro períodos de acuerdo con el embarazo de la terapeuta: (1) terapeuta no estaba embarazada; (2) terapeuta sabía de su gestación, pero el asunto no había sido verbalizado; (3) tema fue tratado en el setting terapéutico; (4) retorno de la licencia por maternidad. Los resultados demostraron una disminución de la neutralidad y de la colocación de límites, y discusión de pausas e interrupciones en el tratamiento. Se concluyó que el embarazo de la terapeuta influye en el setting terapéutico de forma acentuada.
\end{abstract}

Palabras clave: psicoterapia psicoanalítica, psicoterapia del niño, proceso psicoterapéutico

${ }^{1}$ Derived article from Master dissertation of Fernanda Munhoz Driemeier Schmidt under the supervision of Professor Dr. Vera Regina Röhnelt Ramires, defended in 2016, at the Graduate Program in Clinical Psychology of UNISINOS. Support: Financing this study was carried out with the support of the Coordination for the Qualification of Higher Level Staff Brazil (Portuguese acronym: CAPES) - Financing Code 001. And also with the support of the National Council of Scientific and Technological Development (Portuguese acronym: CNPq) - code of processes 471358/2014-2 e 311235/2014-0.

Correspondence address: Fernanda Munhoz Driemeier Schmidt. Universidade do Vale do Rio dos Sinos. São Leopoldo-RS, Brazil. CEP 93.022-000. E-mail: fernandadriemeier@hotmail.com
Psychodynamic psychotherapy is a process aimed at enabling the individual to increase his /her knowledge about his / her psychological functioning, which results in the use of more mature defenses to deal with psychic conflicts, improvement of the pattern of object relations and significant symptomatic changes. This modality of treatment has been effectively used with children for internalization and externalization disorders, character difficulties, poorly adaptive internal responses to stressful events, and increased 
and more flexible defense mechanisms (Kernberg, Ritvo, Keable, \& American Academy of Child Adolescent Psychiatry Committee on Quality Issues, 2012). Although widely practiced, children's psychotherapies rely on a relatively small volume of empirical research to assess their efficacy and effectiveness (Palmer, Nascimento, \& Fonagy, 2013).

In the last 10 years, some systematic reviews have been made focusing on the psychotherapy of children, identifying that most of the studies were naturalistic, focusing on different difficulties, closer to clinical practice, but with a limited degree of influence on the guidelines that lead the bases of evidences. When comparing treatments of different intensities, the more intensive treatments showed greater benefits. It has been found that young children benefit more from psychotherapy and that working with parents is very important. It has been found that research in behavioral psychotherapies is in greater numbers than those of psychoanalytic psychotherapy (Midgley \& Kennedy, 2011; Palmer et al., 2013).

Most studies, up to now, reveal a lack of consideration of how or why certain treatments work and which aspects of treatment tend to facilitate or inhibit therapeutic change (Midgley \& Kennedy, 2011; Palmer et al., 2013; Schneider, Midgley, \& Duncan, 2010). Although research on the process of child psychotherapy has expanded in recent years, the number of investigations that explore the mechanisms of change is still very low. Midgley (2007) reviewed fifteen articles focusing on some aspect of the psychoanalytic psychotherapy process of children, identifying that the studies contemplate the discussion of outcome measures such as child behavior, play, defenses, object relations, therapeutic relationship, but without fully capturing the process of the therapeutic encounter in its complexity.

At the same time, there is growing recognition that the careful exploration of the therapeutic relationship allows us to know the central aspects of the treatment of children and what characteristics of the therapist influence this construction. In this direction, international and national research indicates that the psychotherapist's role in the treatment of children is very important and aspects related to it are associated and are often predictors of the results of psychotherapies (Goodman \& Athey-Lloyd, 2011; Wolfe, 2013). Therefore, studying factors associated with the therapist is fundamental (Wolfe, 2013).

In Brazil, the practice of psychotherapy is mostly performed by women. Of the psychologists registered in the Federal Council of Psychology (Portuguese acronym: CFP), $89 \%$ are female and $34 \%$ of them work with clinical psychology (Lhullier \& Roslindo, 2013). In the population of analysts of children and adolescents linked to the International Psychoanalytical Association (IPA) and Brazilian Association of Psychoanalysis (Portuguese acronym: ABP), $78 \%$ of the members were women in 2000 (Caron et al., 2000). Therefore, studying factors associated with the female gender is very important. The pregnancy of the psychotherapist is perhaps the most important one, since it seems to be quite experienced in clinical practice and little studied through research (Tonon, Romani, \& Grossi, 2012).
In a systematic review on the psychotherapist's pregnancy (Schmidt, Fiorini, \& Ramires, 2015), 22 articles were found, of which 18 were on adult psychotherapy and 4 on child psychotherapy. Only two articles of quantitative methodology and in the area of adults were found, 12 were case reports in which the authors were the therapists themselves, which was repeated in the four articles with child patients. All had psychoanalysis as their theoretical basis. The results indicated that the therapist's pregnancy has an important impact on the psychotherapeutic treatment and that these repercussions affect the patient, the therapist, the therapeutic relationship and, consequently, the process. The authors verified the lack of research on this topic, the need to update the studies and the predominance of qualitative exploratory approaches, with small samples, retrospective collection at the time the psychotherapist was pregnant. These data could be influenced by lapses and memory distortions. No study investigated the patient's perspective and the therapeutic process.

Research on adult patients and children discusses the repercussions of the psychotherapist's pregnancy on treatment (Schmidt et al., 2015, Tonon et al., 2012, Wolfe, 2013). Some point in the direction that pregnancy catalyzes and facilitates various aspects of the process (Tonon et al., 2012; Wolfe, 2013), while others point out the difficulties that may occur in a treatment with the pregnant therapist. However, the literature emphasizes that what will facilitate and / or hinder its progress depends on the therapist, the patient and what both construct together (Schmidt et al., 2015).

In research with children, the papers report that pregnancy emphasizes transference with the psychotherapist. This factor offers a good opportunity to work on developmental difficulties, pre-oedipal issues, problems of separation and individuation, and on the formation of the child's ego (Schmidt et al., 2015).

Researchers and clinicians seem to agree that the psychotherapist's pregnancy is a unique period in the process, because it is a part of the psychotherapist's life that can not be concealed from patients, confronting the concept of neutrality in some way. These findings suggest that the psychotherapist's pregnancy can influence and mark the therapeutic relationship. However, there is no consensus whether the effect is positive or negative for treatment (Schmidt et al., 2015; Wolfe, 2013). Despite the relevance of the topic and its repercussion in psychotherapies, there are few current works, most of them with adult patients. Thus, the present study sought to describe the characteristics of the psychodynamic psychotherapeutic process of a child with a pregnant psychotherapist, and to identify possible repercussions of the therapist's pregnancy in the treatment.

\section{Method}

A naturalistic, descriptive and longitudinal study was carried out, based on the Systematic Case Study (SCS) method (Edwards, 2007). The SCS aims at analyzing the 
psychotherapeutic process and enables the understanding of variables of the patient, the therapist and the interaction between both.

\section{Participants}

Patient: Alice (pseudonym), who was eight years old at the beginning of her psychotherapy. Her mother sought help because the girl had somatic complaints without organic causes. The patient had migraine and crying crises, not wanting to go to school. Alice's father, to whom she was very attached, died suddenly six months before starting treatment. There were changes in the family financial structure and she had to change schools. The mother and the teacher described Alice as a rigid and perfectionist, but very affectionate girl; also, the mother reported concern about her daughter's anguish over sexual matters. All these impressions were confirmed by the therapist. Alice was diagnosed with Adaptive Disorder with anxiety (309.24), according to the DSM-5 (American Psychiatric Association, 2013). Alice studied in the third year of elementary school and resided with her mother and sister (two years younger).

Therapist: The therapist had 10 years of clinical experience when she was sought by the patient. She has a specialization in child psychoanalytic psychotherapy and a doctorate in the same area. She did the clinical supervision of the case under study and was undergoing psychoanalytic treatment. She became pregnant throughout the psychotherapeutic process, and it was her first pregnancy.

\section{Instruments}

Child Psychotherapy $Q$ - Set (CPQ) (Schneider, 2003; Schneider \& Jones, 2004, 2012). CPQ is used to analyze the psychotherapeutic process of children 3 to 13 years of age. This instrument is composed of 100 items, each containing an affirmative that describes a relevant aspect of the treatment process: (a) the child's attitudes; (b) actions and attitudes of the therapist; and (c) the nature of the patienttherapist interaction. The 100 statements were selected from a broad review of studies on children's psychotherapy, which included empirically validated methods and psychoanalytic approaches (Schneider, 2003; Schneider, Pruetzel-Thomas, \& Midgley, 2009). The instrument is applied from videos of psychotherapy sessions. Each statement receives a score ranging from 1 to 9 , according to how much was characteristic of the session, or neutral. A fixed number of items should be placed in each category resulting in a normal distribution. The CPQ was translated and adapted into Brazilian Portuguese by Ramires and Schneider (2016). The reliability and validity of CPQ have been demonstrated by different studies (Gastaud, Carvalho, Goodman, \& Ramires 2015; Goodman \& Athey-Lloyd, 2011; Goodman, Midgley, \& Schneider, 2016; Ramires, Carvalho, Schmidt, Fiorini, \& Goodman, 2015; Schneider, 2003; Schneider et al., 2009, 2010).

\section{Procedures}

Data collection. After the first contact and the interview with the mother, the child was evaluated to confirm the need for psychotherapy. The evaluation was based on interviews with the mother, with the child, in the Rorschach Method, Comprehensive System (Exner, 2003) and CBCL (Achenbach, 1991), answered by the mother and the teacher. Psychotherapy was based on the psychodynamic approach, the sessions of the child lasted 50 minutes and had weekly frequency. Monthly interviews were conducted with the mother to collect additional data and guide her about the psychotherapeutic process.

The therapist knew that she was pregnant during treatment before session seven. The girl began to show signs of perceiving physical changes in the therapist. In session 17 , the pregnancy was revealed, in a play where the roles were reversed and who asked questions was the girl. Alice questioned the therapist if she had children, when the baby would be born, whether the therapist could work while she was pregnant and then said that by the time the baby was born she would be better off and no longer needed treatment. Two sessions later, the mother called the therapist, advising that the girl could not go to the session. The therapist invited her mother to come in instead of the girl and the two talked, among other things, about the pregnancy and concern of the girl if the therapist would suffer the childbirth. The mother reported that Alice was better off with headaches and stomachaches, but that she began to bite her nails and was developing rituals and manias. This was the girl's only absence in all treatment.

After session 24, the mother made a telephone call with the therapist, reporting a worsening of her symptoms and her great resistance to going to school. She reported that Alice said she had many stomach pains and that she had the impression that the girl fantasized that she was pregnant. Between session 31 and 32, the mother phoned the therapist, saying that a very close family member had a serious heart problem but was now at home. The mother resigned from work to care for this family member and claimed she did not have the financial means to keep the treatment. Two sessions were combined that month (eve of the therapist's leave). At session 33, the farewell was made for the maternity leave of the therapist. It was agreed that the therapist would make phone contact when she returned to the activities. Two and a half months after the last session, the therapist made telephone contact attempts with the patient's mother, taking two weeks to get a response.

Before starting the psychotherapy, the proposal of the research was presented to the mother and later to the patient. The therapist had previously been consulted and agreed to participate. The fact that the case participated in the study did not affect the progress of the therapeutic process, which was a priority. It would, however, involve video recording of Alice's sessions. With the agreement of all involved, the Terms of Free and Informed Consent have been signed. Thus, all of Alice's sessions were recorded 
on video with the consent of the therapist and the patient. In total, 40 sessions of psychotherapy were performed, filmed and analyzed. The psychotherapeutic treatment was divided into four stages: the first refers to a period in which the therapist was not pregnant (from session 1 to session 6); the second period corresponds to period in which the therapist knew of her pregnancy but the subject had not been verbalized in the sessions ( 7 to 16 ); the third moment was when the subject was treated in the therapeutic setting, until the moment of maternity leave (17 to 34); and, finally, the fourth period, when the therapist returned from her three-month leave (35 to 40).

Data analysis. To analyze the sessions, six psychologists with clinical experience were trained to use the CPQ coding system. Two judges were randomly designated to the independent evaluation of each session. Videos were encoded in random order. All 40 psychotherapy sessions that took place over a year were analyzed. After watching the videos of the sessions, the judges distributed the items in nine categories ranging from the least characteristic (category 1) to the most characteristic (category 9) of each session. In the intermediate categories the neutral items were positioned. Each session received a final score from the average of the two judges. The concordance between any pair of judges was at least .70 (Cronbach's alpha) and ranged from .69 to .90 ( $m=.80$ and $S D=.05$ ) in the 40 sessions. Each session is considered a unit of analysis for statistical calculations.

The average CPQ items in the 40 sessions revealed the general tone of the treatment, as the average of the items in each of the four stages allowed the characterization of each one of them. To evaluate the CPQ items that varied significantly between the four times of psychotherapy, MANOVA was performed, with the 100 items of CPQ as dependent variables. In this analysis, a significant statistical difference was found in some items between the steps
(Wilks Lambda $p=.016$ ). To identify between which periods the differences were found, the Tukey's Post Hoc test was used. These analyzes were performed using SPSS 23.0.

\section{Ethical Considerations}

The research protocol was approved by the Research Ethics Committee of the University of the Vale do Rio dos Sinos (No 12/030). All international ethical guidelines for human research were followed. All the ethical procedures were respected, giving priority to the well-being of the participants.

\section{Results}

An examination of the fifteen more and less characteristic CPQ items, averaging 40 sessions, captured the overall tone of Alice's treatment. Table 1 summarizes these results. It is observed that the therapist was sensitive, affectively engaged and confident, being able to accurately perceive the therapeutic process (items 6, 9, 86 and 28). The therapist did not structure the session and did not criticize the girl's concerns, helped her manage her feelings, and encouraged the girl to express herself verbally (items $3,17,18,31$, 82 and 97). Thus, Alice was able to express her affection, felt herself understood by the therapist, and answered the questions and the play more elaborately, with comments and/or associations to the therapist's interventions, being willing to examine her thoughts and feelings (items 40, 41, 42 , and 58). The therapeutic session usually had a specific topic or focus, the material worked was related to the main conflicts of the child, and the patient and therapist were attuned, establishing an expected interaction for the girl's developmental phase (items 23, 38, 77 and 88).

Table 1.

The 15 most and least characteristic items in general and in each treatment period.

\begin{tabular}{|c|c|c|c|c|c|}
\hline Items & $\begin{array}{c}\text { Overall } \\
\text { average }\end{array}$ & $\begin{array}{c}\text { Average } \\
\text { time } 1 \\
\end{array}$ & $\begin{array}{c}\text { Average } \\
\text { time } 2 \\
\end{array}$ & $\begin{array}{c}\text { Average } \\
\text { time } 3 \\
\end{array}$ & $\begin{array}{c}\text { Average } \\
\text { time } 4 \\
\end{array}$ \\
\hline \multicolumn{6}{|l|}{ Most characteristic items } \\
\hline $31-\mathrm{T}$ asks for more information or elaboration. & 8.28 & 8.25 & 8.20 & 8.32 & 8,36 \\
\hline $6-\mathrm{T}$ is sensitive to C's feelings. & 8.20 & 8.08 & 8.20 & 8.26 & 8.29 \\
\hline $28-\mathrm{T}$ accurately perceives the therapeutic process. & 8.06 & 7.67 & 7.95 & 8.18 & 8.14 \\
\hline 3 - T's remarks are aimed at encouraging C's speech. & 7.70 & 8.17 & 7.95 & 7.65 & 7.07 \\
\hline 88 - Material of the hour is meaningful and relevant to C's conflicts. & 7.56 & 7.58 & 7.20 & 7.79 & 7.50 \\
\hline 76 - T makes links between C's feelings and experience. & 7.45 & 7.17 & 7.75 & 7.32 & 7.57 \\
\hline 77 - T's interaction with C is sensitive to the C's level of development. & 7.35 & 7.42 & 7.65 & 7.35 & - \\
\hline 23 - Therapy session has a specific focus or theme. & 7.25 & 7.25 & 7.10 & 7.26 & 7.43 \\
\hline 86 - $\mathrm{T}$ is confident, self-assured [vs; uncertain or unsure]. & 7.25 & 7.92 & 7.35 & 7.03 & - \\
\hline 82 - T helps C manage feelings. & 7.16 & 7.00 & 7.50 & 7.18 & - \\
\hline $\begin{array}{l}38 \text { - } \mathrm{T} \text { and } \mathrm{C} \text { demonstrate a shared vocabulary or understanding when } \\
\text { referring to events or feelings. }\end{array}$ & 7.15 & - & 7.30 & 7.09 & 7.36 \\
\hline 67 - T interprets warded-off or unconscious wishes, feelings, or ideas. & 7.10 & - & 7.30 & 7.38 & 7.36 \\
\hline
\end{tabular}


... continuation

\begin{tabular}{|c|c|c|c|c|c|}
\hline Items & $\begin{array}{l}\text { Overall } \\
\text { average }\end{array}$ & $\begin{array}{l}\text { Average } \\
\text { time } 1\end{array}$ & $\begin{array}{l}\text { Average } \\
\text { time } 2\end{array}$ & $\begin{array}{l}\text { Average } \\
\text { time } 3\end{array}$ & $\begin{array}{c}\text { Average } \\
\text { time } 4\end{array}$ \\
\hline 97 - T emphasizes verbalization of internal states and affects. & 7.10 & 7.33 & - & 7.18 & - \\
\hline 64 - C draws T into play. & 7.07 & 6.92 & 7.40 & 7.15 & - \\
\hline 69 - C's current or recent life situation is emphasized. & 7.06 & 8.17 & - & - & 7.36 \\
\hline 81 - T emphasizes feelings to help $\mathrm{C}$ experience them more deeply. & - & 7.25 & - & - & - \\
\hline 65 - T clarifies, restates, or rephrases C's communication. & - & 7.08 & - & - & - \\
\hline 62 - T points out a recurrent theme in the C's experience or conduct. & - & - & 7.30 & - & 7.07 \\
\hline $78-\mathrm{C}$ is compliant. & - & - & 6.90 & - & - \\
\hline $72-C$ is active. & - & - & - & 7.03 & 7.36 \\
\hline $\begin{array}{l}75 \text { - Interruptions, breaks in the treatment, or termination of therapy } \\
\text { are discussed. }\end{array}$ & - & - & - & - & 7.93 \\
\hline 46 - T interprets the meaning of C's play. & - & - & - & - & 7.07 \\
\hline 53 - C conveys awareness of own internal difficulties & - & - & - & - & 7.50 \\
\hline \multicolumn{6}{|l|}{ Least characteristic items } \\
\hline $\begin{array}{l}1 \text { - C expresses negative feelings (e.g., criticism, hostility) towards } \mathrm{T} \\
\text { [vs. express approval or admiration]. }\end{array}$ & 2.86 & 2.92 & 2.50 & - & - \\
\hline $\begin{array}{l}20-\mathrm{C} \text { is provocative; challenges the } \mathrm{T} \text { or rules and boundaries of the } \\
\text { therapy hour. }\end{array}$ & 2.85 & 2.83 & 2.80 & 2.91 & 2.79 \\
\hline 89 - T acts to strengthen existing defenses. & 2.65 & - & 2.55 & 2.59 & 2.64 \\
\hline 49 - $C$ conveys or expresses mixed or conflicted feelings about the $T$. & 2.62 & 2.17 & 2.40 & 2.85 & 2.79 \\
\hline 95 - C's play lacks spontaneity. & 2.45 & 2.50 & 2.35 & 2.50 & 2.43 \\
\hline $\begin{array}{l}58-\mathrm{C} \text { appears unwilling to examine thoughts, reactions, or } \\
\text { motivations related to problems. }\end{array}$ & 2.43 & 2.50 & 2.65 & 2.38 & 2.21 \\
\hline 42 - C ignores or rejects T's comments and observations. & 2.15 & 2.33 & 2.25 & 2.12 & 1.93 \\
\hline 26 - $\mathrm{C}$ is socially misattuned or inappropriate. & 2.02 & 2.25 & 2.10 & 2.03 & 1.71 \\
\hline $\begin{array}{l}17 \text { - T actively exerts control over the interaction (e.g., structuring, } \\
\text { introducing new topics). }\end{array}$ & 1.97 & 2.25 & 1.90 & 1.91 & 2.00 \\
\hline $56-\mathrm{C}$ is distant from his or her feelings. & 1.91 & 1.58 & 2.10 & 1.94 & 1.86 \\
\hline 18 - $\mathrm{T}$ is judgmental and conveys lack of acceptance. & 1.77 & 1.67 & 1.70 & 1.68 & 2.21 \\
\hline 5 - C has difficulty understanding the T's comments. & 1.73 & 1.75 & 1.70 & 1.76 & - \\
\hline 40 - C communicates without affect. & 1.72 & 1.75 & 1.65 & 1.71 & 1.86 \\
\hline 41 - $\mathrm{C}$ does not feel understood by $\mathrm{T}$. & 1.62 & 1.58 & 1.55 & 1.68 & 1.64 \\
\hline $9-\mathrm{T}$ is nonresponsive [vs; affectively engaged]. & 1.12 & 1.25 & 1.15 & 1.09 & 1.07 \\
\hline $57-\mathrm{T}$ attempts to modify distortions in C's beliefs. & - & 2.92 & - & - & - \\
\hline $37-\mathrm{T}$ behaves in a didactic manner. & - & - & - & 2.79 & 2.36 \\
\hline 5 - $\mathrm{C}$ has difficulty understanding the T's comments. & - & - & - & - & 1.71 \\
\hline
\end{tabular}

Note. $\mathrm{C}=$ child; $\mathrm{T}=$ therapist.

When one observes the main characteristics of psychotherapy in each of the four stages, it is observed that, to a large extent, they correspond to the characteristics of the treatment according to Table 2. However, some items have become more protrude in the last two periods: Alice became more active (item 72); in the last step, the interruptions and pauses in the treatment became more discussed (item 75), there was more use of interpretations of the play (46) and greater awareness of the patient's own difficulties (53). The analysis of the statistical significance of the variation of the items revealed that 14 of them varied in a statistically significant way. 
Table 2

Items that ranged between the four treatment periods

\begin{tabular}{|c|c|c|c|c|c|}
\hline \multirow[b]{2}{*}{ Item } & \multirow[b]{2}{*}{ Item description } & \multicolumn{2}{|l|}{ Manova } & \multicolumn{2}{|l|}{ Tukey } \\
\hline & & $F$ & Times & $\begin{array}{l}\text { Difference of averages } \\
\text { between periods }\end{array}$ & $\begin{array}{c}\text { Item } \\
\text { direction }\end{array}$ \\
\hline 4 & There is discussion of why $\mathrm{C}$ is in therapy. & $6.64 * *$ & $\begin{array}{l}1-2 \\
1-3 \\
2-4 \\
3-4\end{array}$ & $\begin{array}{r}1.66^{*} \\
1.59 * \\
-1.68^{*} \\
-1.60^{*}\end{array}$ & $\begin{array}{l}\downarrow \\
\downarrow \\
\uparrow \\
\uparrow\end{array}$ \\
\hline 32 & C achieves a new understanding or insight. & $3.95^{*}$ & $1-4$ & $-2.71 *$ & $\uparrow$ \\
\hline 35 & C's self-image is a theme. & $3.64 *$ & $1-4$ & $-1.52 *$ & $\uparrow$ \\
\hline 43 & $\mathrm{~T}$ suggests the meaning of the behavior of others. & $3.60^{*}$ & $\begin{array}{l}2-4 \\
3-4\end{array}$ & $\begin{array}{l}-.79^{*} \\
-.67 *\end{array}$ & $\uparrow$ \\
\hline 46 & $\mathrm{~T}$ interprets the meaning of C's play. & $3.91 *$ & $3-4$ & $-1.27 *$ & $\uparrow$ \\
\hline 48 & T sets limits. & $4.81 * *$ & $\begin{array}{l}1-3 \\
1-4\end{array}$ & $\begin{array}{l}.72 * * \\
.82 * *\end{array}$ & $\begin{array}{l}\downarrow \\
\downarrow\end{array}$ \\
\hline 54 & $\mathrm{C}$ is clear and organized in verbal expression. & $2.94 *$ & $1-4$ & $.90^{*}$ & $\downarrow$ \\
\hline 61 & $\begin{array}{l}\text { C feels shy and embarrassed [vs; un-self-conscious } \\
\text { and assured]. }\end{array}$ & $4.25^{*}$ & $\begin{array}{l}1-4 \\
2-4\end{array}$ & $\begin{array}{l}2.08^{*} \\
1.60^{*}\end{array}$ & $\begin{array}{l}\downarrow \\
\downarrow\end{array}$ \\
\hline 67 & $\begin{array}{l}\mathrm{T} \text { interprets warded-off or unconscious wishes, } \\
\text { feelings, or ideas. }\end{array}$ & $3.83 *$ & $\begin{array}{l}1-2 \\
1-3 \\
1-4\end{array}$ & $\begin{array}{l}-1.63^{*} \\
-1.76^{*} \\
-1.69^{*}\end{array}$ & $\begin{array}{l}\uparrow \\
\uparrow \\
\uparrow\end{array}$ \\
\hline 69 & C's current or recent life situation is emphasized. & $3.08^{*}$ & $1-3$ & $1.40^{*}$ & $\downarrow$ \\
\hline 75 & $\begin{array}{l}\text { Interruptions, breaks in the treatment, or termination } \\
\text { of therapy are discussed. }\end{array}$ & $7.12 * *$ & $\begin{array}{l}1-4 \\
2-4 \\
3-4\end{array}$ & $\begin{array}{l}-2.51 * * \\
-2.38 * * \\
-2.19 * *\end{array}$ & $\begin{array}{l}\uparrow \\
\uparrow \\
\uparrow\end{array}$ \\
\hline 87 & $\begin{array}{l}\mathrm{T} \text { informs } \mathrm{C} \text { of the potential impact of his or her } \\
\text { behavior on others (not including } \mathrm{T} \text { ). }\end{array}$ & $3.03 *$ & $2-3$ & $-.70^{*}$ & $\uparrow$ \\
\hline 93 & $\mathrm{~T}$ is neutral. & $3.66^{*}$ & $1-3$ & $1.34 *$ & $\downarrow$ \\
\hline 94 & C feels sad or depressed [vs. cheerful and joyous]. & $3.64 *$ & $1-3$ & $.96^{*}$ & $\downarrow$ \\
\hline
\end{tabular}

Note. $\mathrm{C}=$ child; $\mathrm{T}=$ therapist. $* * p<.01 ; * p<.05$

When one observes the main characteristics of psychotherapy in each of the four stages, it is observed that, to a large extent, they correspond to the characteristics of the treatment according to Table 2. However, some items have become more protrude in the last two periods: Alice became more active (item 72); in the last step, the interruptions and pauses in the treatment became more discussed (item 75), there was more use of interpretations of the play (46) and greater awareness of the patient's own difficulties (53). The analysis of the statistical significance of the variation of the items revealed that 14 of them varied in a statistically significant way.

Of the 14 items that varied in some of the four periods of the therapeutic process, eight refer to the child and six to the therapist. From phase one to phase two, two items were found that varied significantly (4 and 67). The first refers to the discussion about why the child is in therapy, which declined in the second phase of the process. The second item that varies is if the therapist interprets the rejected or unconscious desires, feelings or ideas, which increased in the second moment.

In phase three of the treatment, when both knew about pregnancy and worked on some issues related to this subject, the therapist started to interpret the meaning of the child's play more (46) and continued to interpret the patient's unconscious questions (67), placed fewer limits (48), and was less neutral (93). The current situation of the girl's life was less emphasized (69), and she showed signs of being more uninhibited (61), lively and cheerful (94).

In the last phase of the treatment, several items presented variation when compared to some other previous moment. Again, discussions about the reasons for the child being in psychotherapy (4) and the therapist made more comments about the meaning of others' behavior (43). In addition, the therapist interpreted the meaning of the patient's play (46), avoided placing limits (48), and informed the child of the impact that her behavior might have on others (87). She drew attention to the feelings, thoughts or impulses that might not be clear in the girl's consciousness (67). The girl presented more insights from the contents of the session (32), discussing more her feelings and perceptions about herself. She was able to express herself in a way that was easily understood, and she was more uninhibited and more secure (61). It can be noticed that the item referring to the discussion about the end of the treatment showed significant growth over the treatment periods. 


\section{Discussion}

This study presents a first attempt to investigate the psychodynamic psychotherapeutic process of a schoolaged child and her therapist who becomes pregnant during treatment, based on the Q method. The literature has shown that the impact of pregnancy affects both therapist and patient, and that it can be a difficult and more insecure time for children during their treatment (Schmidt et al., 2015).

The CPQ showed elements of the therapeutic process characteristic of psychodynamic psychotherapy, which included the use of interpretations and attention to the therapeutic relationship and transference (Kernberg et al., 2012). This approach favored the girl expressing her feelings through play and verbal interaction, managing to make associations through therapist interventions (Kernberg et al., 2012; Di Osti \& Sei, 2016). Alice quickly joined the therapist and worked on important issues during the sessions that caused her to suffer. In contrast, the therapist used various techniques to assist the girl in communicating her thoughts and feelings and understanding their meanings.

Some CPQ items that have varied throughout the process reflect important characteristics of psychodynamic psychotherapy in children. Discussing why the child is in therapy is a crucial aspect at the beginning of treatment, since addressing this topic helps to establish the therapeutic objectives, clarifying for the child the reasons why he / she is there and thus helping in the establishment of the therapeutic alliance (Kernberg et al., 2012). The presence of this item showed a decrease after the first period and increased again in the latter. This variation can be explained by the fact that, mainly at the end of the process, a resumption of the initial objectives usually occurs, discussing those that were or were not reached with the treatment (Kernberg et al., 2012). Over time, the girl's self-image was discussed more, she seemed less timid and inhibited; seemed less sad and depressed, and showed new understandings and insights about her attitudes and content that emerged in the sessions. These items correspond to the evolution of psychodynamic psychotherapy (Kernberg et al., 2012). At the same time, they point to evidence that the girl has improved, at least in some respects, until the end of treatment.

It was observed that the therapist's pregnancy impacted the therapeutic process. During treatment, CPQ allowed to capture changes in the dynamics of this process, according to the four periods related to pregnancy. Item 54 , on the organization and verbal clarity of the patient, decreased significantly from the first to the fourth phase of psychotherapy. This would not be an expected outcome in psychodynamic psychotherapy and indicates that there were probably still many issues to be addressed before discharge requested by the patient's mother. The fourth phase occurred almost three months after the interruption due to the therapist's maternity leave, and some achievements could have experienced some degree of regression because of this. In addition, one might hypothesize that, because of Alice's obsessive characteristics and defenses, the manifestation of aggressive feelings and her anger at her withdrawal and prospect of closure of psychotherapy was not possible.

The literature suggests that there is an intense involvement of patients with the current moment of the life of psychotherapists. They may feel less important or even excluded from the psychotherapist's life at the time of a prolonged withdrawal, and present regressions in their behavior (Schmidt et al., 2015). In the same direction, the literature of psychodynamic psychotherapy states that children at the end of treatment tend to present some regressive behaviors as a way of expressing their ambivalence towards the completion (Kernberg et al., 2012).

Regarding the items related to the therapist's interventions, it is perceived that the interpretation of the meaning of the play and the interpretation of the unconscious desires, feelings or ideas acquired increasing importance until the end of the treatment. The use of these techniques is a fundamental characteristic of children's psychodynamic psychotherapy (Ferro, 1995). At a time when the therapeutic relationship was already better established and, with this, confidence and intimacy, it probably became possible for the therapist to have a better understanding of the case, being able to interpret the play and deepen the patient's unconscious contents.

On the other hand, in terms of periods 2, 3 and 4, the therapist increasingly suggests the meaning of the behavior of the people in the child's life (item 43) seems to indicate to some extent that she has become less neutral, since this is not a typical practice in psychodynamic psychotherapy. It is interesting to note that this began when the therapist already knew about her pregnancy, but the patient has not yet, and this item has become more significant over time. It is hypothesized that the variation of this item is related to the variation of item 93 , on the neutrality of the therapist, which decreased significantly. According to some studies, it is possible that the therapist's pregnancy reduces her neutrality throughout the psychotherapeutic process (Tonon et al., 2012; Wolfe, 2013), and that information from the real therapist is given (Tonon et al., 2012). In addition, each therapist may present different ways of dealing with the changes and with the reactions of patients to her pregnancy (Schmidt et al., 2015).

Still with respect to neutrality, it should be noted that the girl was going through a time of great vulnerability, since she suddenly lost her father, a close relative was seriously ill, and her therapist had become pregnant and would leave for a period. It is possible that the therapist experienced an unconscious feeling of guilt, having to "abandon" her patient, with this history and under these circumstances, which perhaps explains the reason for not placing limits (item 48), not discussing the child's current life (item 69) and reducing her neutrality (item 93). It is common for the pregnant therapist to feel guilt and feel self-absorbed (Schmidt et al., 2015). This may 
be related to an ambivalence to go ahead with the care or to dedicate all the time to the unborn baby. At the same time, the literature on psychodynamic psychotherapy of children discusses that the technique in this age group requires greater flexibility and negotiation regarding limits, framework and analytical rules (Kernberg et al., 2012), which also suggests that the therapist seems to have tried to adjust to the needs of the girl and the therapeutic process.

Another point to be discussed is the item 87, which describes interventions when the therapist shows the patient the possible impact of her behavior on others. This characteristic has intensified from period 2 to 3 . Here it may also be possible that the pregnancy has had some impact, for it is precisely at that moment that Alice became conscious, at least aware of this fact. The verbalization and discussion of a concrete fact with implications on the therapist-patient relationship may have led both to discuss, at this stage, more concrete questions, rather than to work on the patient's subjectivity and fantasies. In addition to the feeling of guilt experienced by the pregnant therapist towards patients, another difficulty may be to facilitate the expression of aggressive feelings or envy on their part, and in some situations, this dynamic may contribute to a distancing of the patient's affections and a collusion with the patient's denial and avoidance of these affections (Schmidt et al., 2015).

It is noteworthy that in the third period of psychotherapy, when news of the pregnancy was revealed, there were also important issues in Alice's family life and she experienced a worsening of her symptoms. This is the treatment step that presents the highest number of variations in CPQ items. This evidence corroborates the hypothesis about the importance and impact that the therapist's pregnancy may have on the psychodynamic therapeutic process.

In the fourth and last period of treatment, the weather is already farewell. Alice returned to psychotherapy with the number of sessions determined until closure at the request of her mother. This was clearly expressed in the scores of item 75 of the CPQ, which concerns the discussion of interruptions and pauses in treatment, which again grew statistically significant. It should be noted that this item presented significant and increasing variation in all periods of treatment, being something very worked out. This can be explained because this was the patient's main conflict, dealing with losses and separations, which was being concretely revived in the therapeutic setting. The presence of conflicts related to the therapist's pregnancy is natural and even expected for patients in general (Schmidt et al., 2015). However, it was noticed that for Alice they were greatly intensified, perhaps by her psychopathology that was associated with important losses in her life.

It raises the hypothesis that the therapist's relationship with Alice's mother needed more investment and work. Certainly, she was also going through a difficult time of mourning. She was referred to treatment by Alice's therapist, but she did not seek such help, claiming financial difficulties, time and organization of family life to meet all needs and responsibilities. In this way, more frequent follow-up interviews with this mother could have offered more support and, perhaps, prevented the premature closure of Alice's psychotherapy. In addition to the literature points to the need for a good bond with parents (Kernberg et al., 2012) and that children do not seek psychotherapy alone, studies with adult patients have shown that the therapist's pregnancy intensifies in women pre-oedipal conflicts and conflicts regarding femininity and sexuality (Schmidt et al., 2015). While the therapist was waiting for the arrival of a child, Alice's mother experienced an opposite moment in her life cycle, relating to her husband's premature and sudden loss. This factor may have constituted a negative spiral that was not sufficiently perceived and worked, leading to the early abandonment of the treatment.

In summary, the CPQ allowed an accurate description of the therapeutic process in question, as well as the identification of changes in the dynamics of this process over its duration. The significant variation of some of the CPQ items, which describe characteristics of the patient and the therapist in the sessions, and their interaction in the four periods related to the therapist's pregnancy, legitimizes the hypothesis that this factor impacted the therapeutic process.

This result agrees with most studies, which indicate that pregnancy influences the therapeutic setting in a marked way (Tonon et al., 2012). The CPQ allowed to identify a reduction of the psychotherapist's neutrality, a decrease in the placement of limits, a discussion about the reason for psychotherapy, and a discussion of pauses and interruptions in treatment.

Psychotherapy in focus has also been increasingly characterized in the four stages analyzed using the interpretation of the meaning of the play and the unconscious contents by the therapist. The variation of CPQ items in these steps also indicated that the patient's self-image was worked out, she gained new understandings and insights about her difficulties, became more secure and uninhibited, and less sad and depressed.

An important particularity in this case concerns the patient's life moment, who was brought in for treatment a few months after the sudden and premature loss of her father, to whom she was very attached. Thus, the changes observed during the therapeutic process, according to the CPQ, may be related predominantly to this process of mourning, rather than to the pregnancy factor of the therapist. In other patients with the pregnant therapist, we could find different dynamics and variations in the treatment steps, or even no variation associated with the pregnancy factor.

One limitation of this study is that the results of psychotherapy were not analyzed. Although outcome measures had been used systematically, it was decided to focus here the therapeutic process and its vicissitudes, considering the occurrence of the pregnancy of the 
therapist in that course. However, in describing the therapeutic process over time and its nuances and changes, some results and achievements on the part of Alice also became evident.

The empirical knowledge of the psychodynamic psychotherapeutic process during and after the pregnancy of the therapist can assist the clinicians in their conceptualization of similar cases, in the understanding and interpretation of the therapeutic process and in the expansion of the knowledge about the psychotherapy of children. Future studies may explore the possible influence of the therapist's pregnancy on the treatment of children of other age groups, with other psychopathologies and in different family contexts. They can also contribute to the elucidation of the best interventions and technical strategies in these cases, exploring the role of interpretation, neutrality, limits, dimensions of reality and fantasy and the best way to deal with each in the clinical setting in each moment etc.

\section{References}

Achenbach, T. M. (1991). Manual for the child behavior checklist/4-18 and 1991 profile. Burlington, VT: University of Vermont/Department of Psychiatry.

American Psychiatric Association. (2013). Diagnostic and statistical manual of mental disorders (DSM-5) (5th ed.). Washington, DC: Author.

Caron, N. A., Bornhold, I., Mondzrak, V. S., Heck, M. M., Wolf, M. P., \& Fortes, S. D. (2000). Perfil da prática psicanalítica de crianças e adolescentes no Brasil [Profile of psychoanalitical child and adolescent practice in Brasil]. Revista de Psicanálise da Sociedade Psicanalitica de Porto Alegre, 7(2), 317-342.

Di Osti, N. M., \& Sei, M. B. (2016). A importância da família na clínica infantil: Um ensaio teórico-clínico [The importance of the family in children's clinic: A theoretical and clinical essay]. Temas em Psicologia, 24(1), 145-157. doi:10.9788/TP2016.1-10

Edwards, D. J. A. (2007). Collaborative versus adversarial stances in scientific discourse: Implications for the role of systematic case studies in the development of evidencebased practice in psychotherapy. Pragmatic Case Studies in Psychotherapy, 3(1), 6-34. doi:10.14713/pcsp.v3i1.892

Exner, J. E., Jr. (2003). The Rorschach: A comprehensive system (4th ed.). New York, NY: Wiley.

Ferro, A. (1995). A técnica na psicanálise infantil: A criança e o analista: Da relação ao campo emocional. Rio de Janeiro, RJ: Imago.
Gastaud, M. B., Carvalho, C., Goodman, G., \& Ramires, V. R. R. (2015). Assessing levels of similarity to a "psychodynamic prototype" in psychodynamic psychotherapy with children: A case study approach (preliminary findings). Trends in Psychiatry and Psychotherapy, 37(3), 161-165. doi:10.1590/2237-60892014-0059

Goodman, G., \& Athey-Lloyd, L. (2011). Interaction structures between a child and two therapists in the psychodynamic treatment of a child with Asperger's disorder. Journal of Child Psychotherapy, 37(3), 311326. doi:10.1080/0075417X.2011.614749

Goodman, G., Midgley, N., \& Schneider, C. (2016). Expert clinicians' prototypes of an ideal child treatment in psychodynamic and cognitive-behavioral therapy: Is mentalization seen as a common process factor? Psychotherapy Research, 26(5), 590-601. doi:10.1080/1 0503307.2015.1049672

Kernberg, P. F., Ritvo, R., Keable, H., \& American Academy of Child an Adolescent Psychiatry Committee on Quality Issues. (2012). Practice parameter for psychodynamic psychotherapy with children. Journal of the American Academy of Child \& Adolescent Psychiatry, 51(5), 541557. doi:10.1016/j.jaac.2012.02.015

Lhullier, L. A., \& Roslindo, J. J. (2013). As psicólogas brasileiras: Levantando a ponta do véu. In L. A. Lhullier (Org.), Quem é a psicóloga brasileira? Mulher, psicologia e trabalho (pp. 18-51). Brasília, DF: Conselho Federal de Psicologia. Retrieved from https://site.cfp.org. br/wp-content/uploads/2013/07/Quem e a Psicologa brasileira.pdf

Midgley, N. (2007). Researching the process of psychoanalytic child psychotherapy. In E. Kennedy \& N. Midgley (Eds.), Process and outcome research in child, adolescent and parent-infant psychotherapy: A thematic review (pp. 8-53). London, United Kingdom: North Central. Retrieved from http://www.efpp.org/research/ Process\%20and\%20Outcome.pdf

Midgley, N., \& Kennedy, E. (2011). Psychodynamic psychotherapy for children and adolescents: A critical review of the evidence base. Journal of Child Psychotherapy, 37(3), 232-260. doi:10.1080/007541 7X.2011.614738

Palmer, R., Nascimento, L. N., \& Fonagy, P. (2013). The state of the evidence base for psychodynamic psychotherapy for children and adolescents. Child and Adolescent Psychiatric Clinics of North America, 22(2), 149-214. doi:10.1016/j.chc.2012.12.001

Ramires, V. R. R., \& Schneider, C. (2016). Elaboração da versão em português do Child Psychotherapy Q-set. [Development the Brazilian Version of the Child Psychotherapy Q-Set]. Psicologia: Teoria e Pesquisa, 32(3), 1-10. doi: 10.1590/0102-3772e323218 
Ramires, V. R. R., Carvalho, C., Schmidt, F. M. D., Fiorini, G. P., \& Goodman, G. (2015). Interaction structures in the psychodynamic therapy of a boy diagnosed with Asperger's disorder: A single-case study. Research in Psychotherapy: Psychopathology, Process and Outcome, 18(2), 129-140. doi:10.4081/ripppo.2015.195

Schmidt, F. M. D., Fiorini, G. P., \& Ramires, V. R. R. (2015). Psychoanalytic psychotherapy and the pregnant therapist: A literature review. Research in Psychotherapy: Psychopathology, Process and Outcome, 18(2), 50-61. doi:10.4081/ripppo.2015.185

Schneider, C. (2003). The development of the child psychotherapy $Q$-set (Unpublished doctoral dissertation). University of California, Berkeley, CA.

Schneider, C., \& Jones, E. E. (2004). Child Psychotherapy Q-Set Coding Manual. Unpublished manuscript, University of California at Berkeley.

Schneider, C., \& Jones, E. E. (2012). Appendix IB. Child Psychotherapy Q-Set. Coding Manual. In R. A. Levy, J. S. Ablon, \& H. Kächele (Eds.), Psychodynamic psychotherapy research: Evidence-based practice and practice-based evidence (pp. 611-626). Totowa, NJ: Humana Press.

Schneider, C., Midgley, N., \& Duncan, A. (2010). A "motion portrait" of a psychodynamic treatment of an 11-year-old girl: Exploring interrelations of psychotherapy process and outcome using the Child Psychotherapy Q-Set. Journal of Infant, Child, and Adolescent Psychotherapy, 9(2-3), 94-107. doi:10.108 0/15289168.2010.510979

Schneider, C., Pruetzel-Thomas, A., \& Midgley, N. (2009). Discovering new ways of seeing and speaking about psychotherapy process: The Child Psychotherapy Q-Set. In N. Midgley, J. Anderson, E. Grainger, T. NesicVuckovic, \& C. Urwin (Eds.), Child psychotherapy and research: New approaches, emerging findings (pp. 7284). New York, NY: Routledge.

Tonon, C. B., Romani, P. F., \& Grossi, R. (2012). A gravidez da terapeuta e seus reflexos no processo psicoterápico [The therapist's pregnancy and its consequences on the psychotherapeutic process]. Psicologia: Teoria e Pesquisa, 28(1), 87-92. doi:10.1590/S010237722012000100011

Wolfe, E. H. (2013). The therapist's pregnancy and the clienttherapist relationship: An exploratory study (Doctoral dissertation). Retrieved from https://scholarworks.smith. edu/cgi/viewcontent.cgi? article $=2021 \&$ context $=$ theses
Fernanda Munhoz Driemeier Schmidt is a Ph.D. candidate of the Graduate Program in Clinical Psychology at Universidade do Vale do Rio dos Sinos, São Leopoldo-RS, Brazil.

Marina Bento Gastaud is a $\mathrm{PhD}$ in Medical Sciences: Psyquiatry, Postdoctoral Fellow at the Graduate Program in Clinical Psychology at Universidade do Vale do Rio dos Sinos, São Leopoldo-RS, Brazil.

Vera Regina Röhnelt Ramires is a professor of the Graduate Program in Clinical Psychology at Universidade do Vale do Rio dos Sinos, São Leopoldo-RS, Brazil.

\section{Authors' Contribution:}

All authors made substantial contributions to the conception and design of this study, to data analysis and interpretation, and to the manuscript revision and approval of the final version All the authors assume public responsibility for content of the manuscript.

Received: Dez. 19, 2016

1st Revision: Jul. 20, 2017

Approved: Oct. 31, 2017
How to cite this article:

Schmidt, F. M. D., Gastaud, M. B., \& Ramires, V. R. R. (2018). Child psychodynamic psychotherapy and therapist pregnancy: Systematic case study. Paidéia (Ribeirão Preto), 28, e2836. doi:http://dx.doi.org/10.1590/1982-4327e2836 